Botha, R. J. (Nico). \& Hugo, J.-P. Effective Mentoring to Improve Job Satisfaction Among Beginner Teachers at South African Primary Schools

\title{
Effective Mentoring to Improve Job Satisfaction among Beginner Teachers at South African Primary Schools
}

\author{
R. J. Nico Botha ${ }^{* 1}$ \& Jean-Pierre Hugo ${ }^{1}$ \\ *Corresponding Author: botharj@unisa.ac.za \\ 1. University of South Africa, Pretoria, South Africa \\ Received : 2021-05-21 \\ Revised : 2021-07-02 \\ Accepted : 2021-08-12
}

$10.46303 /$ ressat.2021.26 How to cite this paper: Botha, R. J. N. \& Hugo, J.-P. (2021). Effective Mentoring to Improve Job Satisfaction Among Beginner Teachers at
South African Primary Schools. Research in Social Sciences and Technology, 6(3), 64-81. https://doi.org/10.46303/ressat.2021.26

This is an Open Access article distributed under the terms of the Creative Commons Attribution 4.0 International license (https://creativecommons.org/licenses/by/4.0/).

\section{Abstract}

Teachers leaving the profession before age of retirement is an ongoing problem in schools worldwide. While fewer teachers enter the profession each year, the number of teachers leaving the profession has increased. Many teachers listed lack of job satisfaction as a reason for leaving the education profession, while citing the lack of mentoring as a main cause of job dissatisfaction. This study explores the impact of an effective mentoring program at primary schools in the province of Mpumalanga, South Africa to support and improve job satisfaction among beginner teachers entering the profession. This study follows a quantitative approach, consisting of a Likert-scale questionnaire. The sample of the study was a number of 550 teachers (principals, deputy principals, heads of department, teachers and student teachers) from different races and cultures from 50 randomly selected state and private primary schools in Mpumalanga. After comparing the literature with the respondents' data, the researchers found that the development and implementation of a mentoring program in the province of Mpumalanga would positively impacts beginner teachers' job satisfaction, thus indicating a definite need for such a mentoring program.

Keywords: Beginner teachers; mentoring; job satisfaction; primary schools; South Africa

\section{Introduction}

According to Ali (2015), a country that respects its teachers should have an "education system that performs more effectively" (p. 131). The image of teachers has been under scrutiny by the South African public over the last couple of years because of poor learner performance and the underperforming education system. This has negatively affected teachers' self-image and confidence, causing them to leave the profession in massive numbers (Yemisi, 2013; Mirza, 2018; Botha, 2020a). Lytle (2016), however, asserts that teachers leaving the profession is an 
Botha, R. J. (Nico). \& Hugo, J.-P. Effective Mentoring to Improve Job Satisfaction Among Beginner Teachers at South African Primary Schools

ongoing problem worldwide and that the number of teachers leaving the profession are increasing rapidly. In addition, fewer teachers are entering the profession each year.

Earlier studies conducted by, inter alia, Modisaotsile (2012) and Shah et al. (2012), found that motivating teachers to stay loyal to the South African education system is not made any easier by the increasing pressure on teachers regarding the poor performance of learners and constant media reports about the incompetence of teachers. Furthermore, unethical behavior and disillusionment among teachers cause them to become demotivated and experience low levels of job satisfaction. Treputtharat and Tayiam (2014) acknowledged furthermore that teachers' job satisfaction is directly link with their learners' achievements, while Ngan (2015) established that teaching and learning quality could be enhancing when teachers experience job satisfaction.

With this in mind, authors such as Lo et al. (2013) believe that beginner teachers who receive mentoring and support will experience greater job satisfaction and will be more committed to the profession. This statement is supported by Richter et al. (2013) who found that mentoring improves a mentee's support system by providing them with an experienced person who guides them throughout the beginning stages of their teaching career, which will ultimately promote greater productivity and job satisfaction.

In the light of the previous statement, Tahir et al. (2014) indicate that the "process of mentoring enables mentees to become equipped with the necessary skills and knowledge which will improve the academic progress of learners" (p. 394). Research conducted by Hugo (2015) and, more recently, by Mullen and Klimaitis (2021) found that there was indeed a dire need for a mentoring program to improve job satisfaction among teachers when transitioning from one school to another and when entering the profession for the first time (i.e. so-called beginnerteachers).

\section{Purpose of the study and research questions}

It is widely known that the provision of quality teaching at South African schools is one of the greatest challenges facing South Africa at present (Botha, 2020b). As a result, there is currently a huge demand for quality new beginner teachers to enter the system. With this in mind, QuanBaffour and Arkon-Achemfour (2013) stress the fact that School Management Teams (SMTs) in South African schools must focus on the effective mentoring of novice teachers to enhance their job satisfaction to retain them in schools. This study is an attempt to address this shortcoming, as effective mentoring of beginner-teachers to retain them for the profession is currently not taking place effectively in South African schools. With tis in mid, the main research question for this study can now be phrase as follows: How can an effective mentoring program improve job satisfaction among beginner teachers at primary schools in the Mpumalanga province of South Africa? The following research sub-questions guided the study:

- What is the link between job satisfaction and an effective mentoring program?

- What are the benefits and characteristics of an effective mentoring program?

The next section highlights the conceptual framework for the study. 
Botha, R. J. (Nico). \& Hugo, J.-P. Effective Mentoring to Improve Job Satisfaction Among Beginner Teachers at South African Primary Schools

\section{Review of the literature}

\section{The concept of job satisfaction in the education context}

The concept of 'job satisfaction' is defined as an enjoyable or positive emotional condition that a person has towards their job, which is caused by an emotional response to a job's circumstances (Hutabarat, 2015; Salehi \& Taghavi, 2015). Treputtharat and Tayiam (2014) as well as Ali (2015) affirm that teachers who experience job satisfaction within their work environment will work harder and raise their schools' efficiency, thereby enhancing learners' quality of learning and their achievement of the curriculum objectives.

Job satisfaction among teachers is essential because of the role that teachers play in developing learners and the future workforce (Zaheer et al., 2015). Treputtharat and Tayiam (2014) support the previous statement by emphasizing that teachers' job satisfaction is an integral indicator of the effectiveness of a school and the learners' academic performance. This means that teachers who are satisfied in their work environment will be more effective in ensuring their learners' academic progression. When teachers are satisfied in their work environment, their work quality - and the resulting quality of learning they facilitate in their learners - will be higher than that of teachers who experience job dissatisfaction.

Superior-Greenstone (2011) found that mentoring support increases teachers' confidence, promotes job satisfaction, improves classroom management and thus enhances learners' academic achievement. In this regard Salehi and Tagavi (2015) state that "attitudes and feelings affect employees' behaviors, which contribute to the organization's success or failure" (p. 16).

\section{The concept of mentoring in the education context}

Researchers such as Baker-Gardner (2014) as well as Mullen and Klimaitis (2021) defines mentoring as the planned pairing of a more experienced person with a less experienced individual to help with the professional development of the latter to reduce teacher turnover. Mukeredzi et al. (2015), in turn, agree with Nkomo et al. (2018) when explaining mentoring as a one-on-one relationship between a competent, experienced teacher (mentor) and a novice or trainee (mentee). Baker-Gardner (2014) indicates that mentoring is a tool used to bridge this training gap at universities and in practice. Richter et al. (2013) indicate that first-year teaching is usually described as a highly stressful period for beginner teachers. These beginner teachers report lower teacher efficacy and perceive higher levels of occupational stress and emotional exhaustion.

According to Mukeredzi et al. (2015), "promoting the acquisition of knowledge, skills and competencies through education is necessary for the performance of chosen roles that contribute to national economic and social development" (p. 3). Ekechukwu and Horsfall (2015) as well as Kutsyuruba and Godden (2019) indicate that mentoring can be view as the professional development of younger teachers, which promotes the continuous and lifelong development of teachers.

\section{The benefits of an effective mentoring program for beginner teachers}

The process of mentoring has emerged as a professional development technique in education to improve teachers' professional skills through career development (Akhalq et al., 2016). With 
Botha, R. J. (Nico). \& Hugo, J.-P. Effective Mentoring to Improve Job Satisfaction Among Beginner Teachers at South African Primary Schools

this in mind, Smit and Du Toit (2016) state that a mentoring program contributes to beginner teachers' professional development and helps them to develop their full potential. By promoting professional development among newly qualified teachers, mentors enable these beginner teachers to acquire certain skills, which makes them more effective in their new work environment (Kutsyuruba \& Godden, 2019). But what are the benefits of such a mentoring program?

Firstly, mentoring is important to develop the skills of teachers. Authors such as Khan et al. (2016) acknowledge that when an organization focuses on developing employees' skills, the organization increases the employees' performance, which, in turn, enables them to be more productive. This will cause employees to become more satisfied in their work environment and to grow in their commitment towards the organization. According to Akhalq et al. (2016), "mentoring is a two-way process and provides a career path growth and enrichment for the advancement of knowledge to each individual of their respective deficient areas" (p. 436)

Secondly, mentoring increases the productivity of teachers. In their study, Mukeredzi et al. (2015) define the concept of productivity concerning teachers as the "possession of pedagogies within the wider domain of knowledge, skills, attitudes and competences" (p. 3). Van der Weijden et al. (2015) add that "mentors play a significant role in the personal and professional development of academic leaders, as well as on their productivity and performance" (p. 280). This is supported by Mundia and Iravo (2015) who state that "the ability of mentors to implement the mentoring program activities may lead to psychosocial support and career development, and enhance their overall work productivity" (p. 394)

Thirdly, coaching, mentoring and support of novice teachers by more experienced teachers will help these novice teachers to become accomplished teachers and will positively influence learners' academic achievements (Heiney-Smith \& Denton, 2015). In studies conducted by Tahir et al. (2014) as well as Kutsyuruba and Godden (2019), the authors state that it is imperative to improve the teaching performance of beginner teachers. The support and guidance of a more experienced person (mentor) will have a positive effect on the quality and teaching performance of beginner teachers.

Furthermore, Mukeredzi et al. (2015) indicate that mentees who are supported and guided by competent mentors will adapt more easily to their new workload and complex work environment. This is supported by Akhalq et al. (2016) who found in their study that support and assistance are transmitted through observation, discussions, questioning and planning; hence, the assistance of a more experienced person through the process of mentoring will support a less experienced individual with the necessary guidance in their profession.

Moreover, when newly qualified teachers are supported by a mentor who guides and outlines all the requirements in an educational setting, the new teachers will develop into a confident and committed workforce that experiences a sense of empowerment within their new work environment (Mirza, 2018). According to Ukil (2016) and Onyemaechi (2019), employee empowerment is a relatively new concept that makes staff more proactive and self-sufficient; and when employees are empowered, they feel that they are a core asset to the organization, which creates a sense of belonging, builds trust, promotes communication and increases organizational effectiveness. 
Botha, R. J. (Nico). \& Hugo, J.-P. Effective Mentoring to Improve Job Satisfaction

Among Beginner Teachers at South African Primary Schools

Lastly, Renbarger and Davis (2019) explain that when communication is listed as an effective tool within any work environment, it has been found to improve job satisfaction, productivity and job performance, as well as binding people together in an organization through the adoption of the values of an organization in order to promote the organizations goals and objectives. Asamu (2014) as well as Watson (2020), more recently, stress the importance of effective communication on the performance and job satisfaction of workers in any organization. This view of Asamu is supported by Onjoro et al. (2015) who state that "effective communication to staff and students would go a long way in increasing their efficiency and effectiveness, since it will help them to be clear about what, how and when to perform" (p. 12).

Mentoring is therefore an effective way to ease the transition for beginner teachers entering the profession. This study sought to investigate how a mentoring program could improve job satisfaction among beginner teachers at primary schools.

\section{Research methods}

\section{Research design and data collection instrument}

This empirical study follows a quantitative approach with a Likert-scale questionnaire.

\section{Research sample}

The study sample consisted of 1000 teachers (male and female and from different races and cultures) from 50 randomly selected and diverse primary schools in the province of Mpumalanga, all within a $300 \mathrm{~km}$ radius from each other. A total of 1000 questionnaires were handed out at 50 schools, comprising rural primary schools, inter-city primary schools and private primary schools. A number of 20 participants per school were requested to complete the Likert-scale questionnaire. It took approximately 20 minutes to complete each questionnaire. Out of the 1000 questionnaires delivered to these schools, 550 (55\%) questionnaires were completed and collected by the researchers in person from the principal of each participating school.

\section{Research ethics}

The 550 respondents in this study remained anonymous. Permission was requested using a covering letter, sent together with the questionnaire, explaining the study's extent and what would be done with the respondents' information. The respondents were assured that none of the information they provided would link them to the study and that no names or any information regarding the respondents would be disclosed to the public or in writing. The respondents were provided with a participant information letter in the form of a cover letter, attached to the questionnaire. The cover letter explained to the respondents the study's purpose, the respondents' role in the study, the expected duration of participation, the guarantee of privacy, anonymity and confidentiality, withdrawal without penalty, the institution giving ethical approval for the research and the researcher's contact details.

Participation in the study was voluntary and the respondents' permission was obtained to use the information gathered during the study. The first step towards obtaining informed consent was to apply for ethical clearance from the research institute (University of South Africa) to conduct research under the guidance of a research study leader appointed by the University of 
Botha, R. J. (Nico). \& Hugo, J.-P. Effective Mentoring to Improve Job Satisfaction Among Beginner Teachers at South African Primary Schools

South Africa. After obtaining clearance to conduct the research, the researchers received written permission from the Mpumalanga Department of Education to enter the selected schools.

\section{Data analysis and presentation}

The data analysis process was planned before data were collected. Information was gathered from the literature review and was evaluated to obtain ideas and formulate research questions about the research topic by identifying recurring themes and keywords. The empirical data collected were analyzed by means of descriptive statistics, which included frequencies and percentages in order to answer the research questions. According to Neuman (2011), descriptive statistics describe numerical data and the easiest way to describe numerical data of one variable is by means of frequency distribution. The descriptive method was consequently used to indicate the spread of a sample across a wide range of variables (De Vos et al., 2012). In other words, the Likert-scale questionnaire helped the researchers to indicate on which level most respondents felt the same about an assumption of a question.

The software used to translate the empirical data from the study were the SPSS22.0 software package, while the Varimax rotation statistical technique, the Kaiser-Meyer-Olkin (KMO) test, Bartlett's test of Homogeneity of Variances and the Cronbach's Alpha coefficient were used as for the statistical analysis of the obtained data. These techniques enabled the researchers to evaluate and translate the data gathered from the respondents in order to investigate how to develop and implement an effective mentoring program at primary schools, and, in addition, how such a mentoring program could support and improve job satisfaction among beginner teachers at primary schools.

After the collection of data, the data were analyzed and divided into categories where the different themes that correlated with one another were identified while the relevant data were captured. The frequency distribution method was used, which, according to Brink et al. (2007) is "a systematic arrangement of the lowest to the highest score linked with the number of times the score occurs" (p. 37). The Likert-scale questionnaire, combined with the frequency distribution method, enabled the researchers to draw up a table illustrating the factors that would most probably have the greatest impact on how mentoring could improve beginner teachers' job satisfaction at schools in Mpumalanga province. Histograms, bar charts, pie charts and graphs were constructed to present and explain the data in more detail. The data gathered during the empirical investigation were compared with the literature study to allow a proper comparison between the literature and the data gathered. The quantitative data were analyzed to determine findings and recommendations for this study.

The descriptive statistics (biographical data) were presented in the form of bar graphs from which explanations of the findings were presented. The analysis of the data obtained from the Likert-scale questionnaires were presented, while the data gathered in this section of the study were structured to answer the research questions. Comparisons were drawn between male and female principals, deputy principals, heads of departments, teachers and student teachers from rural primary schools, private primary schools and Quintile 4 and 5 primary schools (schools are ranked in South Africa according quintiles according to the financial situation of the school with quintile 4 and 5 schools being the poorest). In using the data provided by 
Botha, R. J. (Nico). \& Hugo, J.-P. Effective Mentoring to Improve Job Satisfaction Among Beginner Teachers at South African Primary Schools

participants, it was determined whether there is a correlation between their beliefs regarding effective mentoring to improve job satisfaction among beginner teachers at South African primary schools. The analysis of the data gathered from respondents allowed the researchers to identify critical aspects regarding the effect of mentoring on the job satisfaction among beginner teachers. The factors are as follows:

- Factor 1: Aspects in the work environment assisting teacher satisfaction and supporting learner achievement.

- Factor 2: Aspects of how an effective mentoring program can contribute to job satisfaction of beginner teachers.

By utilizing the factors, the researchers aimed to investigate how an effective mentoring program can be utilized to improve job satisfaction among beginner teachers at primary schools in the Mpumalanga province of South Africa.

\section{Results}

\section{What is the link between job satisfaction and an effective mentoring program?}

Participants were requested to identify contributing aspects in their work environment that could promote teacher satisfaction and, in the process, improve learner achievement. Four items probed teachers' perceptions about their contribution to job satisfaction. The items were mostly about the work environment and, hence, were very broad as such an environment could include a whole host of factors.

The Varimax rotation statistical technique was used at one level of factor analysis as an attempt to clarify the relationship among factors. In maximizing the variance generally means to increase the squared correlation of items related to one factor, while decreasing the correlation of any other factor (Hugo, 2015). Principal components (PCA) with the Varimax rotation resulted in only one factor, which explained $76.66 \%$ of the variance present and had a Cronbach alpha of 0.895 .

This factor (Factor 1) was named 'Aspects in the work environment promoting teacher satisfaction and supporting learner achievement'. The items and their mean scores and factor loadings are given in table 1.

Table 1. Items with mean scores and factor loadings in Factor 1

\begin{tabular}{|l|l|r|r|}
\hline \multicolumn{2}{|l|}{$\begin{array}{l}\text { Factor analysis - Aspects in the work environment assisting teacher satisfaction and } \\
\text { supporting learner achievement }\end{array}$} & Loading \\
\hline Item & $\begin{array}{l}\text { Description: Extent of the work environment that } \\
\text { contributes to teacher satisfaction and learner } \\
\text { achievement }\end{array}$ & Mean & 0.912 \\
\hline 3 & $\begin{array}{l}\text { Teachers satisfied with the work environment devote } \\
\text { more time to help learners to achieve their goals. }\end{array}$ & 5.43 & 0.912 \\
\hline 32 & $\begin{array}{l}\text { Teachers satisfied with the work environment devote } \\
\text { more energy to help learners to achieve their goals. }\end{array}$ & 5.49 & 0.905 \\
\hline 4 & $\begin{array}{l}\text { Teachers satisfied with the work environment devote } \\
\text { more attention to help learners to achieve their goals. }\end{array}$ & 5.47 & 5.26 \\
\hline 1 & Enhancement of teaching and learning & 5.41 & 0.764 \\
\hline Average & & \\
\hline
\end{tabular}


Botha, R. J. (Nico). \& Hugo, J.-P. Effective Mentoring to Improve Job Satisfaction Among Beginner Teachers at South African Primary Schools

The mean score of 5.41 indicates strong agreement with the items in the factor "aspects in the work environment assisting teacher satisfaction and support learning achievement. As all items fell within the 'totally agree' interval of the Likert scale, data distribution is likely to be negatively skewed. This is shown in figure 1 .
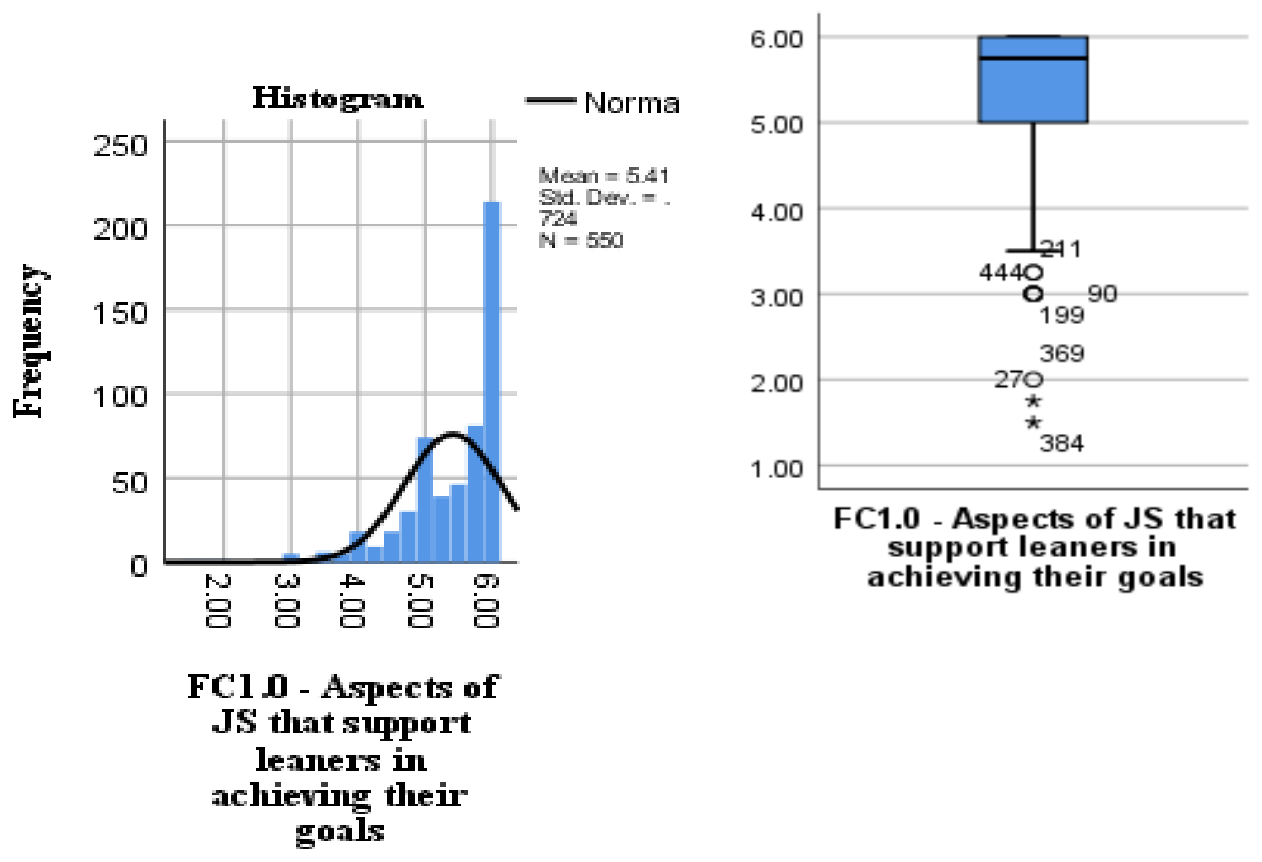

Figure 1. Histogram and boxplot showing the data distribution of items in Factor 1

The data distribution was negatively skewed, which was expected because of the way in which the items were posted. The boxplot shows some outliers (especially respondents 384 and 270), but they were not removed, as non-parametric procedures will be utilized in further testing of this factor. The mean of 5.41 and median of 5.75 shown in table 1 above, confirm the skewness of the data distribution.

\section{What are the benefits and characteristics of an effective mentoring program?}

Participants were requested to identify possible benefits and characteristics of an effective mentoring program. These could include aspects of how an effective mentoring program can contribute to job satisfaction among beginner teachers. Once again, four items probed teachers' perceptions with regard benefits and characteristics of an effective mentoring program for beginner teachers.

The Kaiser-Meyer-Olkin (KMO) test and Bartlett's test of Homogeneity of Variances were both used at this level of factor analysis. The KMO test is a measure of how suited data is for factor analysis (between 0.8 and 1.0 indicate the sampling is adequate), while Bartlett's test of Homogeneity of Variances is a test to identify whether there are equal variances of a continuous variable across two or more groups of independent variables. Its' main aim is to test the null hypothesis of no difference in variances between groups. The KMO value of 0.814 and 
Botha, R. J. (Nico). \& Hugo, J.-P. Effective Mentoring to Improve Job Satisfaction Among Beginner Teachers at South African Primary Schools

Bartlett's sphericity of $p=0.000$ indicate that a PCA with Varimax rotation would reduce the four items to a more economic number of smaller factors. The resulting one factor explains $72.91 \%$ of the variance present and has a Cronbach reliability of 0.874 .

This factor (Factor 2) was named 'Benefits and characteristics of an effective mentoring program'. The items and their mean scores and factor loadings are given in Table 2.

Table 2: Items with mean scores and factor loadings in Factor 2

\begin{tabular}{|l|l|r|r|}
\hline \multicolumn{3}{|l|}{$\begin{array}{l}\text { Factor analysis - Aspects of how an effective mentoring programme can contribute to job } \\
\text { satisfaction of beginner teachers ( } \alpha=0.874)\end{array}$} & 0.875 \\
\hline Item & $\begin{array}{l}\text { Description: Extent of contribution to job satisfaction of } \\
\text { beginner teachers }\end{array}$ & Mean & Loading \\
\hline 3 & $\begin{array}{l}\text { Adaptation of beginner teachers to the new work } \\
\text { environment }\end{array}$ & 5.29 & 0.869 \\
\hline 2 & $\begin{array}{l}\text { The possibility of using mentorship as a management tool } \\
\text { to enhance job satisfaction among beginner teachers in a } \\
\text { new work environment }\end{array}$ & 5.34 & 0.84 \\
\hline 4 & $\begin{array}{l}\text { Need for school management to identify strategies, such } \\
\text { as effective mentoring programmes at primary schools, to } \\
\text { support the improvement of job satisfaction among } \\
\text { beginner teachers }\end{array}$ & 5.32 & 0.831 \\
\hline 1 & $\begin{array}{l}\text { The possibility of enhancing job satisfaction among } \\
\text { beginner teachers at primary schools }\end{array}$ & 5.25 & 0.854 \\
\hline Average & 5.30 & 0 \\
\hline
\end{tabular}

The item with the highest mean score, which the respondents strongly agreed with, is item 2, namely the possibility of using mentorship as a management tool to enhance job satisfaction among beginner teachers in a new work environment. The high mean scores for each item suggest that the data will negatively skew distribution (Figure 2).
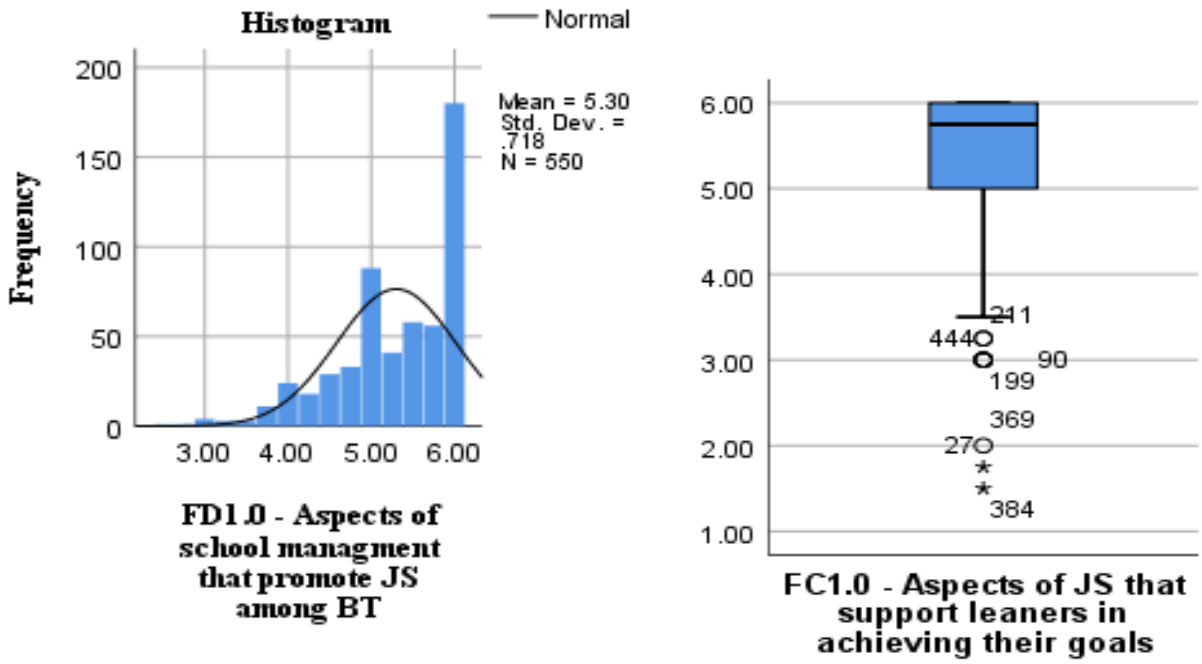

Figure 2. Histogram and boxplot showing the data distribution of items in Factor 2 
Botha, R. J. (Nico). \& Hugo, J.-P. Effective Mentoring to Improve Job Satisfaction

Among Beginner Teachers at South African Primary Schools

The mean score of 5.30 and a medium of 5.50 indicate that the respondents strongly agreed with the factor items. The distribution is negatively skewed and non-parametric procedures will be utilized for further analysis. The next section of this article will discuss the findings and will be done according to the research sub-questions phrased earlier.

\section{Discussion}

\section{Factor 1: What is the link between job satisfaction and an effective mentoring program?}

The first research sub-question was aimed at determining whether there is a link between mentoring and job satisfaction. The theoretical framework clearly outlined a definite link between job satisfaction and mentoring, as most of the theory found that mentees (beginner teachers) would experience job satisfaction. Baker-Gardner (2014) confirms that there is a definite link between the mentoring that a mentee receives and the mentee's job satisfaction. Thus there is a clear link between receiving mentoring and the job satisfaction experienced by newly qualified teachers. Toropova et al. (2021) state in this regard: "Most schools need satisfied and motivated teachers who can work effectively and efficiently for the attainment of school goals and productivity" (p. 72).

The findings regarding job satisfaction and mentoring during the literature review allowed the researchers to formulate questions into a Likert-scale questionnaire. These questions were aimed at determining whether primary school teachers in the province of Mpumalanga would agree in such a way that the findings from the literature review would correlate with the findings from the respondents. The literature review identified different theoretical factors that would affect teachers' job satisfaction negatively, which would cause teachers to become dissatisfied in their work environment. These factors would cause teachers to experience different forms of unpleasant emotional responses to their work environment.

After the data had been processed, some correlations were made between the literature reviewed and the respondents' answers. The correlations indicated clearly that when teachers experienced work-related stress, inadequate opportunities for training and development, frustration with learner discipline, a dysfunctional work environment and inadequate leadership support, they experience burnout, low levels of commitment, absenteeism and discouragement, factors which could increase teacher turnover. Research conducted by Toropova et al. (2021) supports the previously mentioned findings, namely that job satisfaction has a direct and negative relationship with employees' turnover.

The Likert-scale questionnaire provided respondents with the opportunity to indicate if they agreed with the theoretical framework. The literature portrayed findings of teachers' experiencing job satisfaction when they were part of a mentoring program. After comparing the theories with the respondents' data, the researchers found that the development and implementation of a mentoring program in the province of Mpumalanga would positively influence beginner teachers' job satisfaction, indicating that there is a definite need for such a mentoring program.

This type of mentoring program would enhance teaching and learning; teachers would devote more time and energy to helping learners to achieve their academic goals, while program would help beginner teachers to adapt to their new working environment. The respondents indicated 
Botha, R. J. (Nico). \& Hugo, J.-P. Effective Mentoring to Improve Job Satisfaction Among Beginner Teachers at South African Primary Schools

that they agreed to a large extent that such a mentoring program would support and improve job satisfaction among beginner teachers, as indicated in the literature reviewed. The following figure portrays the findings and illustrates the link between job satisfaction and an effective mentoring program.

Factors affecting teacher job satisfaction in a negative way include...

work-related stress, inadequate opportunities for training and development, frustration with learner discipline, a dy sfunctional work environment and inadequate leadership support.

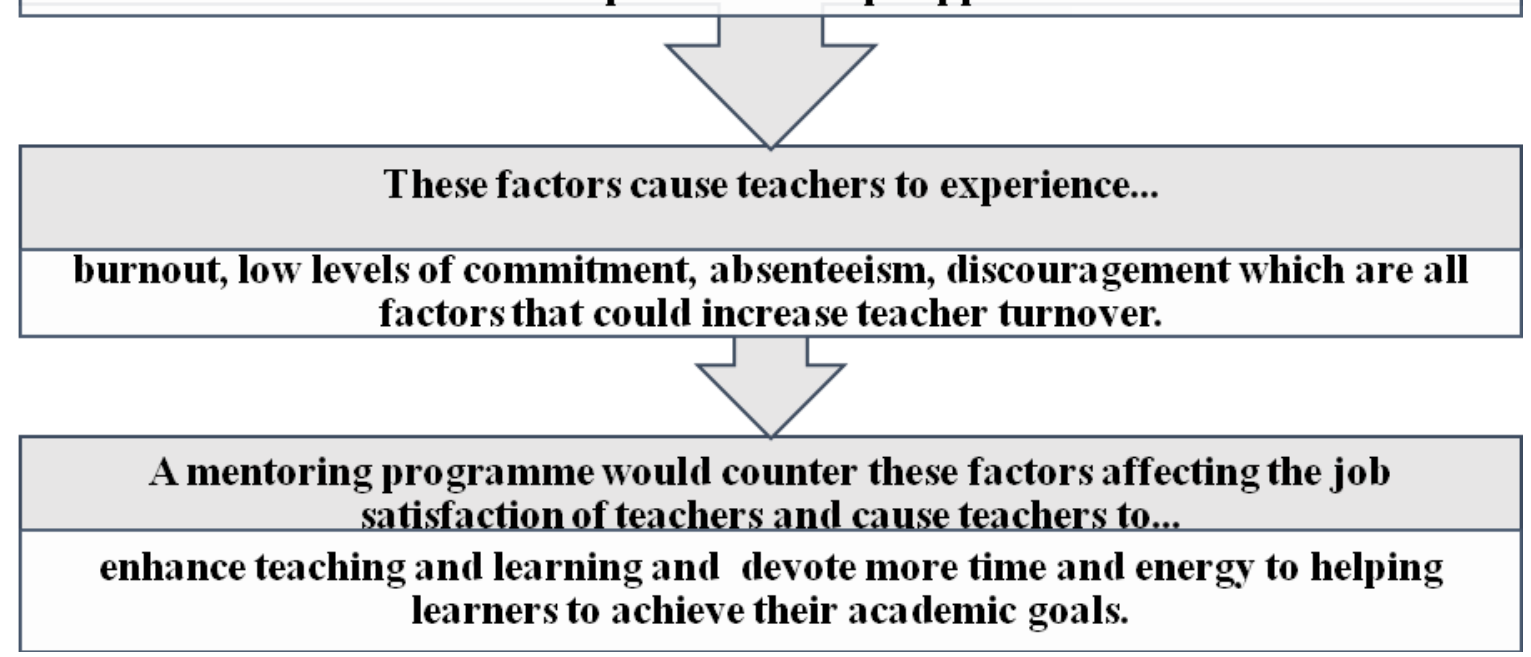

Figure 3. The link between job satisfaction and an effective mentoring program

\section{Factor 2: What are the benefits and characteristics on an effective mentoring program?}

The second research sub-question was aimed at determining the benefits and characteristics on an effective mentoring program suitable for primary schools in the province of Mpumalanga. The conceptual framework presents these benefits and characteristics. The concepts covered indicate that an effective mentoring program should provide structural support, focus on individuals' professional support, provide guidance to mentees and focus on beginner teachers' school-based development. Chester (2015) indicates that the intention of a mentoring program "is to provide teachers with a systematic structure of support that helps them be efficacious, become familiar with their school and district, refine their practice, and better understand their professional responsibilities" (p. 12). All the characteristics mentioned above of an effective mentoring program identified in the conceptual framework were also identified in the first research sub-question as factors that would improve job satisfaction among beginner teachers.

The findings regarding this factor allowed the researchers to formulate questions to ask the respondents in a Likert-scale questionnaire. These questions were aimed at determining whether respondents would agree in such a way that the findings from the conceptual framework would correlate with the findings from the respondents. The conceptual framework 
Botha, R. J. (Nico). \& Hugo, J.-P. Effective Mentoring to Improve Job Satisfaction Among Beginner Teachers at South African Primary Schools

identified different benefits and characteristics of an effective mentoring program, which enabled the researchers to identify which should be considered when developing a mentoring program. Questions included in the Likert-scale questionnaire provided respondents with the opportunity to indicate if they agree with the literature review.

The concepts portrayed findings of these benefits and characteristics. After comparing the literature review with the respondents' data, the researchers found that the development and implementation of a mentoring program in the province of Mpumalanga would positively influence beginner teachers' job satisfaction and that there is a definite need for such a mentoring program. Research conducted by Onyemaechi (2019) supports this study's findings, namely that this type of mentoring program would contribute to professional development, skills development, personal support and emotional support for teachers and create a sense of empowerment and improve their communication skills.

The seven items on the questionnaire probed respondents' perceptions regarding these benefits and characteristics. The same six-point interval on the Likert scale as used previously was utilized to gather these data.

Table 3. Items with mean scores and factor loadings in Factor 2

\begin{tabular}{|c|c|c|c|}
\hline \multicolumn{4}{|c|}{$\begin{array}{l}\text { Factor analysis: The benefits and characteristics of an effective mentoring program ( } \alpha= \\
0.931 \text { ) }\end{array}$} \\
\hline Item & Description: Contribution of mentoring to the following: & Mean & Loading \\
\hline 1 & Provide professional development for beginner teachers. & 5.40 & 0.829 \\
\hline 2 & Provide skills development for beginner teachers. & 5.35 & 0.846 \\
\hline 3 & $\begin{array}{l}\text { Provide personal support to beginner teachers to cope with } \\
\text { the new work environment. }\end{array}$ & 5.40 & 0.875 \\
\hline 4 & $\begin{array}{l}\text { Provide emotional support to beginner teachers to cope with } \\
\text { the new work environment. }\end{array}$ & 5.33 & 0.823 \\
\hline 5 & Create a sense of empowerment among beginner teachers. & 5.36 & 0.842 \\
\hline 6 & $\begin{array}{l}\text { Help beginner teachers with problem-solving opportunities } \\
\text { to use the knowledge acquired in meaningful activities and } \\
\text { to assist them in working at higher levels of thinking. }\end{array}$ & 5.36 & 0.826 \\
\hline 7 & $\begin{array}{l}\text { Provide mentees with appropriate content knowledge to be } \\
\text { more effective in the subject that they teach and thereby } \\
\text { improve learners' learning. }\end{array}$ & 5.34 & 0.845 \\
\hline \multicolumn{2}{|c|}{ Average } & 5.36 & 0.841 \\
\hline
\end{tabular}

The mean score of 5.36 shows that respondents largely agreed with the factor items. Item 1 (benefits and characteristics of an effective mentoring program regarding beginner teachers' professional development) and item 3 (benefits and characteristics of an effective mentoring program for beginner teachers to cope with the new work environment) have the highest mean scores, namely 5.40. The data distribution of the items in this factor is likely to be negatively skewed. The distribution is negatively skewed, as was expected, with a mean of 5.36; hence, non-parametric procedures will be utilized for further testing. This is shown in table 3 above. 
Botha, R. J. (Nico). \& Hugo, J.-P. Effective Mentoring to Improve Job Satisfaction Among Beginner Teachers at South African Primary Schools
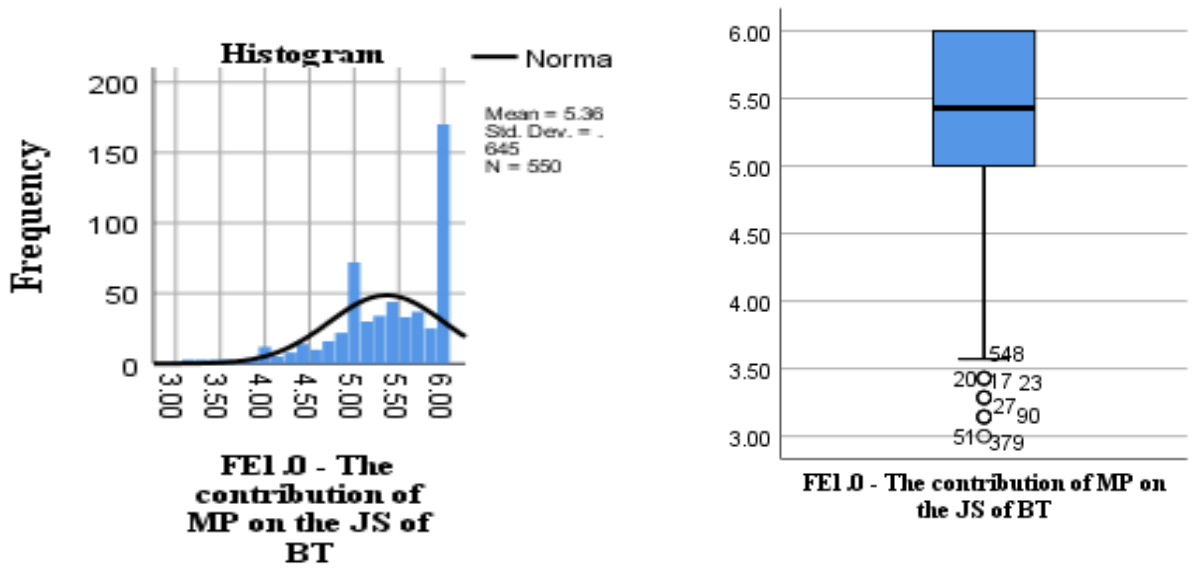

Figure 4. Histogram and boxplot showing the data distribution of items in Factor 2

Figure 5 consequently illustrates the perceived benefits and characteristics of an effective mentoring program.

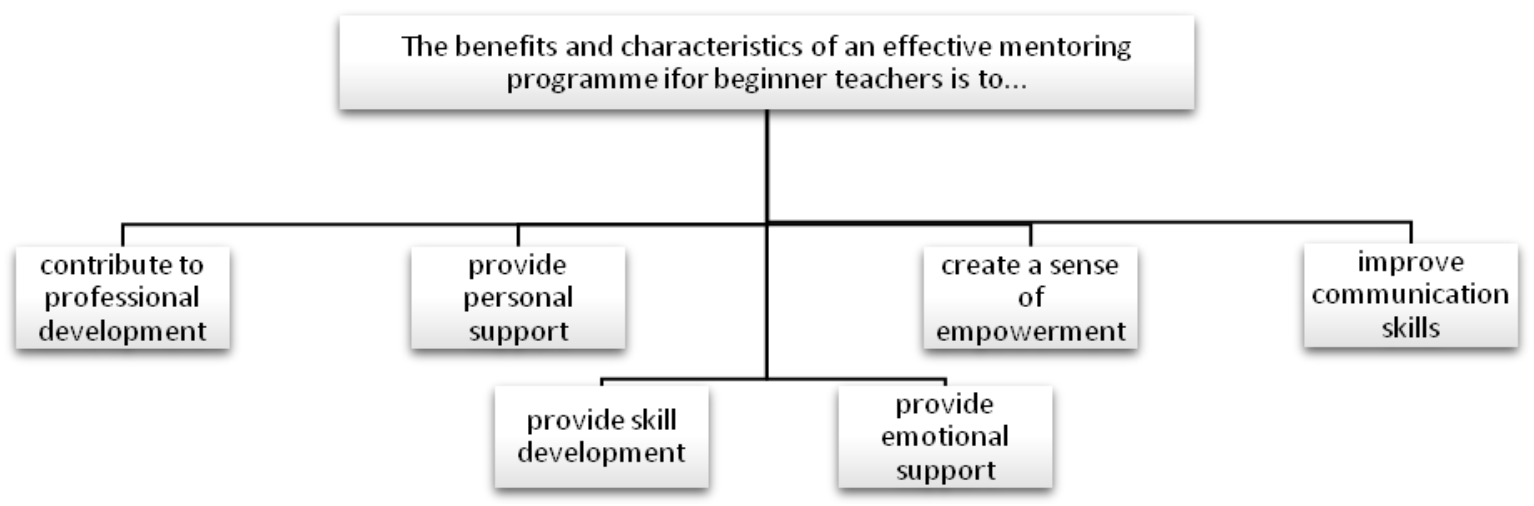

Figure 5. The benefits and characteristics of an effective mentoring program

\section{Limitations of the study}

The primary goal of this study was to explore practices that could help to develop a mentoring program to improve job satisfaction among beginner teachers. This quantitative study had some possible limitations during the data gathering process. These include, inter alia:

- Some of the respondents have ignored the instructions on how to complete the questionnaire provided on the questionnaire cover page. This limitation could have been overcome by briefly highlighting the most important steps in completing the questionnaire. 
Botha, R. J. (Nico). \& Hugo, J.-P. Effective Mentoring to Improve Job Satisfaction Among Beginner Teachers at South African Primary Schools

- Schools might not have wanted to participate in the study. The researchers contacted the 50 participating schools to determine if they would like to participate in the research and to prepare the principals for the Likert-scale questionnaires' arrival.

- Schools could have delayed the data analysis process by not completing the questionnaires in time. When contacting the 50 participating schools, the researchers emphasized the completion date.

\section{Recommendations from the study}

The recommendations are made to improve primary school teachers' job satisfaction through the development and implementation of a mentoring program.

\section{Recommendation concerning research sub-question 1: What is the link between job satisfaction and an effective mentoring program?}

The following recommendation is based on this study's findings, which could improve beginner teachers' job satisfaction. When considering the development and implementation of a mentoring program to improve job satisfaction, the factors that influence job satisfaction should be considered. School management is usually responsible for implementing a mentoring program and should be knowledgeable regarding factors that might influence their teachers' job satisfaction.

Factors that should be considered are a dysfunctional work environment, inadequate leadership support, inadequate training opportunities, frustration with student discipline issues and work-related stress. School management can identify teachers who experience job dissatisfaction by monitoring teachers who show signs of burnout, discouragement, low levels of commitment and increased teacher turnover and absenteeism. If all of the aforementioned factors are taken into account and dealt with by school management when implementing the mentoring program, the management would find that teachers would devote more time and energy to help learners to achieve their goals, which, in turn, would enhance teaching and learning.

\section{Recommendation concerning research sub-question 2: What are the benefits and characteristics of an effective mentoring program?}

Before the process of developing a mentoring program can start, the benefits and characteristics of the program should be identified and evaluated to ensure that it is suitable and viable for the environment in which it will be implemented. Therefore, a mentoring program for beginner teachers in an educational setting (school environment) should, inter alia,

- ensure the professional development of beginner teachers;

- contribute to skills development;

- provide personal and emotional support to beginner teachers in their new work environment;

- create a sense of empowerment;

- provide a work environment where beginner teachers can acquire knowledge to solve problems; and 
Botha, R. J. (Nico). \& Hugo, J.-P. Effective Mentoring to Improve Job Satisfaction Among Beginner Teachers at South African Primary Schools

- provide content knowledge regarding a specific subject area to ensure the learners' academic success.

In summary, the mentoring program should ensure a beginner teacher's professional development to ensure learners' academic success.

\section{Conclusion}

The purpose of this study was to investigate how an effective mentoring program could support and improve job satisfaction among beginner teachers at primary schools in the province of Mpumalanga. The study identified a series of factors regarding mentoring that school management teams could consider and implement to help beginner teachers cope in their new work environment, thereby improving teachers' job satisfaction and retention. From the data gathered, the importance of a mentoring program was evaluated and described. The study also provided key aspects that should be taken into consideration when managing a mentoring program.

As seen throughout this study, mentoring has the ability to counter different factors affecting job satisfaction amongst beginner teachers in a negative way. The researchers found that the development of a mentoring program would help teachers manage their classroom in a more effective way and thus improve the academic achievements of learners. School management who implement mentoring programs in order to create a work environment where beginner teachers are provided the opportunity to seek guidance from an experienced teacher who support them in their new profession. Throughout this mentoring program, mentors provide knowledge and insight to beginner teachers, which enable them to become more productive and acquire new skills in, for example, classroom management. This can be done when mentors observe their mentees while teaching to identify areas that need improvement and areas in which they excel. Mentees are provided with the opportunity to observe their mentors who set an example of how to behave, manage and engage learners and staff in a teaching environment. This will provide beginner teachers with opportunities to gain a theoretical and practical understanding of schools and classroom environment.

\section{References}

Akhalq, M., Chishti, S.H., \& Iqbal, M.Z. (2016). Activity-based teaching and learning through mentoring in Punjab Province of Pakistan: An analysis. Mediterranean Journal of Social Sciences, 7(1), 434-443.

https://www.mcser.org/journal/index.php/mjss/article/view/8770

Ali, A. (2015). Job satisfaction of teachers according to their academic degrees: A case study of the secondary school teachers in the Iranian province of Mazandaran. Journal of Economics and Sustainable Development, 6(2), 31-135. https://iiste.org/Journals/index.php/JEDS/article/view/19375

Asamu, F.F. (2014). The impact of communication on workers' performance in selected organizations in Lagos State, Nigeria. IOSR Journal of Humanities and Social Science, 19(8), 75-82. http://www.iosrjournals.org/iosr-jhss/papers/Vol19-issue8/Verson2/K019827582.pdf 
Botha, R. J. (Nico). \& Hugo, J.-P. Effective Mentoring to Improve Job Satisfaction Among Beginner Teachers at South African Primary Schools

Baker-Gardner, R. (2014). A proposed model for the induction of new teachers in Jamaican primary schools. International Journal of Education and Research, 2(12), 283-296. https://ijern.com/journal/2014/December-2014/25.pdf

Botha, R. J. (2020a). Making a difference in South African schools: The cases of two female principals. Gender and Behavior, 16(1), 10812-10823. https://www.ajol.info/index.php/gab/article/view/175271

Botha, R.J. (2020b). Kontekstuele invloede op skoolhoofde: 'n Studie in Suid-Afrikaanse skole (Contextual influences of school principals: A case study in South African schools). BLinNet (Akademies), 17(1), 490-510. https://www.litnet.co.za/wpcontent/uploads/2020/04/LitNet Akademies 17-1 Botha 490-510.pdf

Brink, H., Van der Walt, G., \& Van Rensburg, G. (2007). Fundamentals of research methodology for health care professionals ( $2^{\text {nd }}$ ed.). Cape Town: Juta \& Company Ltd.

Chester, M.D. 2015. Guidelines for Induction \& Mentoring Programs: Providing comprehensive supports to prepare and retain effective educators and to develop leaders.

Massachusetts: Massachusetts Department of Elementary and Secondary Education. https://www.doe.mass.edu/edeffectiveness/mentor/teachers.html

De Vos, A.S., Strydom, H., Fouché, C.B. \& Delport, C.S.L. 2012. Research at grass roots (4th ed.). Pretoria: Van Schaik Publishers.

Ekechukwu, R.O., \& Horsfall, M.N. (2015). Academic mentoring in higher education: A strategy to quality assurance in teacher education in Nigeria. European Journal of Research and Reflection in Educational Sciences, 3(2), 37-45.

Heiney-Smith, J., \& Denton, D.W. (2015). Mentoring as professional development: Enhancing mentor programs to impact student achievement. Curriculum in Context, Spring edition, 15-19.

Hugo, J. (2015). Support strategies by school principals to enhance job satisfaction amongst male teachers in the Ehlanzeni School District, Mpumalanga. Unpublished Master's dissertation, Pretoria: University of South Africa.

http://uir.unisa.ac.za/handle/10500/19902

Hutabarat, W. (2015). Investigation of teacher job-performance model: Organizational culture, work motivation and job satisfaction. Journal of Asian Social Science, 11(18), 295-304.

Khan, A.A., Abbasi, SOBH, Waseem, RM, Ayaz, M., \& ljaz, M. (2016). Employee performance through job satisfaction: A study of Telecom Sector of Pakistan. Business Management and Strategy, 7(1):29-46.

http://www.macrothink.org/journal/index.php/bms/article/view/9024

Kutsyuruba, B., \& Godden, L. (2019). The role of mentoring and coaching as means of supporting the well-being of educators and students. International Journal of Mentoring and Coaching in Education, 8(4), 229-234.

Lo, M.C., Ramayah, T., \& Kui, L.C. (2013). Mentoring and job satisfaction in Malaysia: A test on small medium enterprises in Malaysia. International Journal of Psychology, 13, 6990.https://www.vdu.lt/cris/bitstream/20.500.12259/31811/1/ISSN2345$\underline{024 X 2013 \vee \text { 13.PG } 69 \text { 90.pdf }}$ 
Botha, R. J. (Nico). \& Hugo, J.-P. Effective Mentoring to Improve Job Satisfaction Among Beginner Teachers at South African Primary Schools

Lytle, N.E (2016). The relationship among teacher job satisfaction, trust in the principal and principal support, Dissertations, theses and masters projects. Paper 1463413079. http://dx.doi.org/10.21220/W47P4X

Mirza, S. (2018). Impact of Mentoring on At-Risk Youth. Research in Social Sciences and Technology, 3(1), 36-53. https://doi.org/10.46303/ressat.03.01.3

Modisaotsile, B.M. (2012). The failing standard of basic education in South Africa. Education Institute of South Africa, March 3(72), 2-8.

https://www.purpletod.co.za/docs/FAILING\%20STANDARDS.pdf

Mukeredzi, T.G., Mthiyane, N., \& Bertram, C. (2015). Becoming professionally qualified: The school-based mentoring experiences of part-time PGCE students. South African Journal of Education, 35(2), 1-9. https://www.ajol.info/index.php/saje/article/view/118007

Mullen, C. A., \& Klimaitis, C. C. (2021). Defining mentoring: a literature review of issues, types, and applications. Annuals of the New York Academy of Sciences, 1483(1): 19-35. https://nyaspubs.onlinelibrary.wiley.com/doi/epdf/10.1111/nyas.14176

Mundia, C.N., \& Iravo, M. (2014). Role of mentoring programs on employee performance in organizations: A survey of public universities in Nyeri County, Kenya. International Journal of Academic Research in Business and Social Sciences, 4(8), 393-412. https://doi.org/10.6007/IJARBSS/v4-i8/1110

Neuman, W.L. (2011). Social research methods: Qualitative and quantitative approaches (7th ed.). Boston: Pearson.

Ngan, T.D.K. (2015). Factors influencing job satisfaction of professors in universities in Jo Chi Minh City. International Journal of Innovative and Applied Research, 3(2), 41-54.

Nkomo, M.W., Thwala, W.D., \& Aigbavboa, C. (2018). Influence of mentoring functions on job satisfaction and organizational commitment of graduate employees. Education and Learning Sciences, 5(20), 97-206.

Onjoro, V., Argo, R.B., \& Embeywa, H.E. (2015). Leadership motivation and mentoring can improve the efficiency of a classroom teacher and workers in institutions. Journal of Education and Practice, 6(15), 1-14. https://files.eric.ed.gov/fulltext/EJ1079967.pdf

Onyemaechi, U. (2019). Effective mentoring practice on employee's performance: A case study of Ania State. International Journal of Management Sciences and Business Research, 8(2), 44-52.

Quan-Baffour, K.P., \& Arko-Achemfour, A. (2013). The effects of a lack of career path on job satisfaction among South African teachers. Anthropologist, 15(1), 25-32. https://doi.org/10.1080/09720073.2013.11891289

Renbarger, R., \& Davis, B. (2019). Mentor, self-efficiency, or professional development: Which mediate job satisfaction for new teachers? A regression examination. Journal of Teacher Education and Educators, 8(1), 21-34. https://files.eric.ed.gov/fulltext/EJ1214939.pdf

Richter, D., Kunter, M., Lüdtke, O., Klusmann, U. \& Anders, Y. (2013). How different mentoring approaches affect beginning teachers' development in the first years of practice. Teaching and Teacher Education, 36,166-177.

Salehi, H., \& Taghavi, E. (2015). Teacher job satisfaction and their attitudes towards their learners in the case of Iranian EFL teachers. Journal of English Language and 
Botha, R. J. (Nico). \& Hugo, J.-P. Effective Mentoring to Improve Job Satisfaction Among Beginner Teachers at South African Primary Schools

Literature, 2(2), 15-26.

https://research.iaun.ac.ir/pd/hadisalehi/pdfs/PaperM 2929.pdf

Shah, M.J., Rehman, M., Akhtar, G., Zafar, H. \& Riaz, A. (2012). Job satisfaction and motivation of teachers of public educational institutions. International Journal of Business and Social Science, April 3(8), 271-281.

http://www.ijbssnet.com/journals/Vol 3 No 8 Special Issue April 2012/31.pdf

Smit, T., \& Du Toit, P.H (2016). Transforming beginner teachers mentoring interventions for social reform. South African Journal of Education, 36(3), 1-12.

http://dx.doi.org/10.15700/saje.v36n3a1134

Superior-Greenstone. (2011). Mentoring Handbook for New Teachers and Mentors. Available at: http://www.sgdsb.on.ca/upload/documents/mentoring-program-hand bookaugust-2013.pdf (Accessed 4 February 2021).

Tahir, L.M., Said, M.N.H.M, Ahmad, R. Daud, K., Sumitono, B., \& Yusoff, S. (2014). Exploring the induction programme for novice teachers. Life Science Journal, 11(8), 394-406.

Toropova, A., Myrberg, E., \& Johansson, S. (2021). Teacher job satisfaction: The importance of school working conditions and teacher characteristics. Educational Review, 73(1), 7197. https://doi.org/10.1080/00131911.2019.1705247

Treputtharat, S., \& Tayiam, S. (2014). School climate affecting job satisfaction of teachers in primary education, KhonKaen, Thailand. Social and Behavioural Sciences, 1(16), 9961000. http://dx.doi.org/10.1016/i.sbspro.2014.01.334

Ukil, M.I. (2016). The impact of employee empowerment on employee satisfaction and service quality: Empirical evidence from financial enterprises in Bangladesh. Business: Theory and Practice, 17(2), 178-189. DOI:10.3846/btp.2016.651

Van der Weijden, I., Belder, R., Van Arensbergen, P., \& Van den Besselaar, P. (2015). How do young tenured professors benefit from a mentor? Effects on management, motivation and performance. High Education, 69, 275-287.

Watson, E. (2020). \#Education: The Potential Impact of Social Media and Hashtag Ideology on the Classroom. Research in Social Sciences and Technology, 5(2), 40-56. https://files.eric.ed.gov/fulltext/EJ1265239.pdf

Yemisi, A.C. (2013). The influence of gender, age, training and experience on teachers' motivation in Ado and Efon local government areas, Ekiti State, Nigeria. Greener Journal of Educational Research, May 3(3), 138-143.

Zaheer, N., Sharif, M.T., Yaqub, RMS, \& Baig, F.J. (5015). Factors affecting job satisfaction at public sector secondary schools of Rahim Yarkhan. Developing Country Studies, 5(5), 27-31. 